\title{
Free and Open Indo-Pacific in Defense Cooperation between Indonesia and Australia
}

\author{
Yoedhi Swastanto Soedarman \\ Former Director General of Defense Strategy of the Indonesian Ministry of Defense \\ yoedhiswastanto83@gmail.com
}

\section{Budi Pramono}

Permanent Lecturer at the Defense University examunhan@gmail.com

\section{Mhd Halkis}

Correspondence Author: Secretary of the Defense Diplomacy Study Program, Faculty of Defense Strategy, University of Defense, Jakarta-Indonesia

halkis@idu.ac.id

\begin{abstract}
Indonesia and Australia are two neighboring countries with different cultural characteristics and patterns of international relations. This research aims to formulate a pattern of strategic partnerships between Indonesia and Australia in the field of defense cooperation. Through the symbolic interactional approach, the researcher saw actors' behavior between countries by collecting data from various sources; online newspapers, scientific articles, interviews, and discussions illustrated the pattern of defense cooperation between Indonesia and Australia at three levels. At the multilateral level, the relationship between Australia and Indonesia looks rather difficult to reciprocate. At the regional level, especially in the Southeast Asia region, Indonesia and Australia cooperation in non-binding control, and on the bilateral level Indonesia and Australia as equal partners are equally committed to mutual control. Free and Open Indo-Pacific strengthens Indonesia-Australia cooperation in the trade sector. An agreement has been built and ratified into the Indonesia-Australia Law comprehensive economic partnership agreement (IA-CEPA). Thus the internal politics of the alliance is very dynamic. On the one hand, the United States strengthens its dominance by utilizing regional countries challenging Chinese policies as bilateral partnerships. On the other hand, multilateral allies help each other. Development between border countries in various ways for defense development.
\end{abstract}

Keywords. Free and Open Indo-Pacific, political alliance, defense cooperation, IA-CEPA, Asymmetrical Security and ASEAN.

\section{Introduction.}

This research looks at the defense cooperation pattern between Indonesia and Australia in the Free and Open Indo-Pacific context. The fluctuation of defense relations between Indonesia and Australia was highest when Indonesia fought for independence in 1948-1949, and the lowest was during Indonesia's confrontation with Malaysia and Britain from 1963-1966 [1]Indonesia in the Suharto era for 23 years was the most intimate when Australian Prime Minister Paul Keating was in power (1991-1996). 
Australian investors came to Indonesia, especially in the mining sector. This relationship was well maintained until Suharto resigns, and entered into critical relations again when Timor Leste left Indonesia [2]

The defense cooperation relationship approach is expected in this study to be a critical review of the post-second world war relational approach, which is constrained by global security alliances on the one hand and narrow regionalization on the other. Researchers assume that regional relations occur to manage bilaterally and multilaterally to achieve better national interest in a country (Christian Echle, Patrick Rueppel, Megha Sarmah, 2018) [4]. In fact, intense global competition is between the United States and Europe. It will be a new challenge if a strong candidate country will emerge (China, Russia, India, Turkey, Indonesia, etc.) to resolve regional scale conflicts [5]. The seepage of global and regional power is not always linear with member countries' interests that have long participated in global and regional competitions. For this, it needs to be proven in the relationship between Indonesia and Australia.

Australia's bilateral relationship with the United States is powerful. Australia's critical support is urgently needed as an impartial oversight, even if it is too late. Australia has obtained arguable benefits when judged by calculating Australia's national interest. A critical review of US policy to reinforce US foreign policy's potentially damaging aspects [6]. In line with the policy of US President Donald Trump, who has announced an Indo-Pacific Strategy related to maritime affairs, especially freedom of navigation, Australia needs to take critical sides. Because after all the Chinese diplomatic movement is seen as an ambition to become a global power in the region that will affect Japan, India, and Australia. The Indo-Pacific idea is an effort to increase defense cooperation with the United States [7],

However, the "Free and Open Indo-Pacific" strategy is not in line with Indonesia's interests, which are Open and Exclusive. In practice, "Free and Open Indo-Pacific" positively affects Australia's relationship with Indonesia. There are three assumptions; First, Indonesia adheres to a "free and active" foreign policy globally, while Australia, the allied state, dominates global interactions. Second, in the US-allied regional areas using the "Free and Open Indo-Pacific" strategy, Indonesia is the ASEAN's unofficial leader. Third, at the bilateral level, Indonesia and Australia need each other and become good friends comprehensively. [8].

Within the three levels, each depends on three indirect dimensions to change a situation not specific to security or economic problems; First, acknowledge each party that needs each other and coordinate opportunities for mutual interests. Second, as relationships improve and the likelihood of defection increases, control also increases. Third, when interest increases, there is reduced sanctioning of defectors making strategies to safeguard mutual interests more difficult [9]. Security cooperation communities exist that are natural and exist in order to maintain balance. If you look at the shape, there are five types: great power, combined community, pluralistic community, collaborative security organization, and collective security systems. All of these security collaborations are based on the identity of transnational members. [10] Stability can be seen as a system's tendency to balance, including its ability to find a new equilibrium in changing conditions. This approach is reflected in five types of Asia-Pacific stability avoidance of major wars, the stability of distribution of power, stability of institutions and norms, political stability within countries, and economic stability [11]

\section{Methodology}

This study uses an ethnographic-transnational approach. Each country is understood to have a behavior pattern based on its innate characteristics coloring the culture depicted in history. Ethnography in a certain way since ethnographic studies began as a methodology that can open up new perspectives in studying world politics, ethnography is used by critical International Relations scholars to base everyday life as a source of credible knowledge about the international world [12]. Initially, in anthropological studies, the ethnographic approach was used to directly examine the wilderness people to deepen the people's minds and culture. In the research phase, understanding the concepts and strategies of the Free and Open Indo-Pacific by the United States is essential to understand and explore, according to the United States itself, because Australia as a target is part of the allied country. 
Researchers realized when they met directly and delved into the target countries' minds that they were making adjustments to the objects they faced, namely the researchers themselves representing Indonesia as an apparatus even though they were doing research.

For this reason, the ethnographic-transnational approach is intended to study the concept, vision, implementation strategy and responses or reactions from others in the context of cooperation between countries. If a single study of the Indonesia-Australia relationship provides a test that is very likely to support or reject a theory, but in this case, many countries are involved, then the things that make Australia a secondary country appear inconsistent with the primarily allied countries. What Australia achieves advantage in this partial implementation is, of course, paid for by compensation or hedging in maintaining the trust of its allied countries? Because it will be difficult for allies, especially Japan, to accept, when Australia accepts cooperation with China, maybe here in the United States' role as the allied countries' main power. This way of working is more on a critical paradigm reflection. Despite the shortcomings of this approach, it creates a new room for interpretation in understanding new phenomena, in this case, asymmetric security issues.

By taking steps to collect data through internet media and interviews with target parties, then confirming with experts both party a and party $b$ is carried out, then analysis and classification are carried out. Then make comparisons with similar expert opinions. Researchers collect data from various sources through internet media, interviews, and scientific articles. Similarities and differences in perceptions about Indo-Pafisik from the Indonesian and Australian sides, which have implications for defense cooperation at each level, are researchers' concerns. Cooperation is a necessity, but differences need to be considered. The efforts of rationality and mutual benefit are the basic principles of good cooperation to be developed in the future. It is hoped that foreign security cooperation policymakers will be more careful in our era.

\section{Results}

There are four forms of defense relations between the two countries, namely alliances, partners, assistance, and hostilities [13]. This form of relationship has been given since the second world war, and it has an effect on multilateral and bilateral forums. From a historical perspective, the relationship between Indonesia and Australia is neither an alliance nor a hostile one, of course, in the form of partners or assistance. In the concept of partnering and rocks, some are dominant, and some are parallel. Indonesia and Australia are seen when at the global level, Australia is more dominant because it is bound by an allied alliance. However, when the Indonesian region is more dominant because Indonesia is the core of ASEAN, and relations between countries are more on equality partners.

\subsection{Multilateral}

Indonesia and Australia are both UN countries; the difference is that Australia, as an ally country, has a more dominant power than Indonesia as a non-aligned member. The position of allied countries is more dominant in this international forum, compared to non-aligned countries, at least because allied countries that are members of the Security Council have veto power. Indeed, there has been a shift in the interaction between members of the United Nations after and before the cold war, but it does not really mean anything for Australia and Indonesia because the arrangement of international relations in the region is more on ASEAN and Indo-Pacific issues. Australia has togetherness as a commonwealth country with Malaysia-Singapore. Even Australia has its own commitment to regional security. This coalition was formed by a collection of British Commonwealth member countries in the Asia Pacific area, named the Five Power Defense Arrangements (FPDA). The commitments formed between the UK, Australia, New Zealand, Malaysia, and Singapore were signed in 1971. [14]. This commitment was until things returned to regular and British troops were withdrawn [15].

The Indo-Pacific issue, by the United States, Japan, and India, raised the Free and Open Indo Pacific (FOIP) strategy. The objective of this strategy is to face China's economic and military developments, albeit with different interests and backgrounds. The United States has an interest in maintaining its hegemony in the region as the most resilient country in the military field. Military strength at sea 
supports the mobility of American and allied trade routes to various countries. Of course, with China's BRI, several trade routes overlap and have the potential to shift trading activities that have been formed so far. Indeed, China does not intend to fight the United States; China presents a development program, not in the framework of being a friend or foe [16]. To support China's BRI program and facilitate domestic trade channels, Indonesia has a "World Maritime Policy" program.

Then Japan and China apart from having an unresolved island dispute, but more than that, China had deep wounds over the treatment of Japanese soldiers. Then China, with India, besides the dispute in the Himalayas, is also a strategy that has never been defeated by India. In contrast, South Korea calls it south-south relations, and Australia is tied to the United States as an ally, but by offering cooperation as a solid basis for strengthening the regulatory-based order in the Indo-Pacific (Kaura, 2020). Australia's desire seems to want to institutionalize this regional cooperation, while President Trump is more on bilateral relations. Before falling into a serious problem, Australia must be able to position itself through studies involving experts in the United States, China, Japan, India, and Indonesia [18]. For this reason, the concept of Free and Open Indo Pacific is not purely from the United States, but an accumulation of surrounding countries to unite against China [19]

Australia has an interest in Indonesia, no less important than the United States. Australia's alliance relationship with the United States is a redefined asset, with shared interests that go far beyond the bilateral economic relations that Australia is becoming part of the international system. Australia's relationship with Indonesia is fundamentally important.

International actors have departed from the alliance paradigm instead of embracing partnerships. Australia sees Indonesia as a very important partner; therefore, it is important to build mutual awareness continuously [20]. However, in the Australian White Paper, the United States is part of Australia's future. Without the strength of the United States, Australia finds it difficult to achieve the security and stability it desires. For this reason, the United States' commitment is important to be lasting to the Indo-Pacific [21]

\subsection{Regional}

In 1967, when the cold war erupted between the west and the east, formally, there were five foreign ministers from the Southeast Asia region who initiated the establishment of ASEAN. Indonesian Foreign Minister Adam Malik became a legend for Indonesians as the father of ASEAN. Until now, Indonesia has raised many concerns about the Southeast Asian Region. Australia sees Indonesia as a strategic partner in the Indo-Pacific region. In the researcher interview with the Secretary-General of the Australian Ministry of Defense, Mr. Greg Moriarty (2019) assessed that Indonesia is the core of ASEAN countries. Indonesia is able to maintain the regional lebensraum dynamically. Australia has a commitment to the Papua issue, supports Indonesia's sovereignty in accordance with the UN Security Council Resolution. It is thus seen that Australia has an interest in Indonesia. However, Australia, as an ally country, certainly sided with United States policies.

In the era of Donald Trump's leadership, the principle is to build relations between countries in the Indo-Pacific region with the principle of "with the US or not." It is as if the Regional States are told to vote as friends or as opponents for Indonesia. ASEAN's view of the Indo-Pacific is related to President Joko Widodo's vision, which is based on inclusivity, openness, close cooperation, and respect for international law with ASEAN as a node for cooperation development. This can be done in the form of the East Asia Summit, ASEAN + 1, the Asian Regional Forum, and the ASEAN Defense Minister Plus Meeting. [22]

According to the Governor of the Indonesian National Defense Institute, Agus Widjojo, at the Quadrilateral 1.5 Track Security Dialogue (10 October 2019, Sydney), explained that Indonesia took a neutral stance. The relationship between Indonesia and China is for reasons of investment programs that are easy and needed by Indonesia at this time. If allied countries offer the same program, then Indonesia will also choose that program. Indonesia continues to position the US as the dominant partner. Learning from the South China Sea conflict, Indonesia can still act decisively. Indonesia changed BRI as a strategic relationship between countries like China into a pattern of investment partnerships in economic development; out of the ASEAN Regional Comprehensive Partnership, it was seen that Indonesia would 
unite regional countries that were already polarized by the US vs. China. While Australia has two faces with Indonesia, on one side of its foreign relations, it seems distant because of the United States' FOIP; however, in the economic sector, Australia maintains relations with Indonesia as a market and resource. When Australia gets the priority choice, then Australia will prioritize economic relations without leaving allies with the United States [23].

\subsection{Bilateral}

The leaders between the two countries will try to jointly maintain good relations, but the political leader is influenced by the conditions of the society he dreams of. There are only a few leader characters who like to find opponents rather than looking for more friends. For this reason, the relationship between the two countries has inhibiting and supporting factors. The first inhibiting factor for the relationship between Indonesia and Australia was mutual suspicion between the Australian and Indonesian people. For Australia, seeing that the majority of Indonesia's population is Muslim can deviate from the potential terrorist threat, while the Indonesian people remain suspicious of Australia's involvement in the separation of Timor Leste from the Unitary State of the Republic of Indonesia, and are now suspicious of any non-state efforts to separate Papua Province from Indonesia. Then, some Indonesians also continued to suspect Australia as part of the United States' alliance. '[24]. Not all Indonesian people like the leadership of the United States, which automatically reflects the existence of Australia.

The supporting factor is mutual interest in the economic and political fields. Australia's Indonesia trade balance is always a surplus for Australia from year to year, and vice versa. Sales of cattle and electronics are the most prominent, on the Indonesian side being the coal and rubber mining market. Meanwhile, in the political sector, Indonesia faces problems in overcoming insurgency in West Papua, and Australia has the potential to be involved in petrifying Indonesia. Likewise, on the other hand, because Indonesia is the gateway to Southeast Asian and West Asian countries, Indonesia's role plays a role in facilitating Australia to its export destination areas.

From the above description, it can be concluded that the ups and downs of Indonesia's defense relationship are influenced by non-defense conditions at each level. The issue of defense is important because it is the last force in protecting the interests of every country. The partnership pattern relationship at each level can be described as follows;

\begin{tabular}{|c|l|}
\hline Level & \multicolumn{1}{|c|}{ Relationship } \\
\hline Multilateral & $\begin{array}{l}\text { Indonesia } \\
\text { Allied blocks, non-aligned (Alliance vs alienation) }\end{array}$ \\
\hline Southeast Asia region & $\begin{array}{l}\text { Indonesia } \\
\text { Australia }\end{array}$ \\
\hline Bilateral & $\begin{array}{l}\text { Indonesia } \\
\text { Comprehensive strategic partner, mutual control }\end{array}$ \\
\hline
\end{tabular}

Picture: the form of partnership between Indonesia and Australia

\section{Discussion}

Since 2013 developing connectivity, communication, and global cooperation through the Belt and Road Initiative (BRI) strategy [25]. To respond to China's BRI strategy in the Asia-Pacific region, the United States developed the Free and Open Indo-Pacific Strategy. The entry of various regional countries in China's BRI can change goods and services, activities and trade will shift [25]. Each country has guidelines for formulating a strategy, and their allies bind allied countries; non-aligned countries also have a perspective in building relations between their countries. The differences between the two countries can also be seen regarding the nature of the agreement's commitments, multilateralism versus bilateralism, strategic geography, and what level of development they have, which are of particular interest to the similarities between the two countries. The politics of maintaining alliances is very subtle and the various allied nations are now allies more on goals than on means of support. (Wesley, 2017,10). 
The United States' concerns about military and economic capabilities are decreasing, and China is increasing. Xi Jinping's April 2014 visit to the Pacific region, including Australia and New Zealand, shows his commitment to building a comprehensive strategic partner [25]. As an allied bloc until early 2020, Taiwan has lost seven countries out of 22 countries for diplomatic recognition [26], including the Solomon country, since months in June 2019 changed its diplomatic direction from Taiwan to China. Australia provides a favorable framework for the US and allies like Australia to enhance cooperation in safeguarding critical elements of a stable Indo-Pacific based regulation [27]. According to Rory Medcalf (2019), there are four Chinese interests towards Australia; want to weaken the alliance through Australia, Australia holds the secrets and strength of the alliance, Australia is an independent power in the IndoPacific, and Australia is home to the Chinese community so that it is easy to build a common interest in the defense sector.

Defense cooperation that has been carried out and has the potential to be developed includes cooperation contracts for consultation and dialogue, exchange of intelligence data, counter-terrorism and counter-insurgency, cooperation in science and technology, human resource development, military student exchanges, joint exercises, and the introduction of reciprocal access to facilities. , SAR Cooperation and Humanitarian and Natural Disaster Aid [29]. From the Australian perspective, Defense cooperation in military operations can be carried out; headquarters can be occupied by multinational, modular operational formations, integrated operational formations, permanent command transfers, and specialization roles [30].

The discussion about the post-1982 UNCLOS sea regime is a political issue rather than a legal one. Freedom of navigation through the Strait of Malacca and the South China Sea has actually been regulated in this way, but it remains a concern for the country to support each country's trade. The busiest trade route in the world is a very complex study. Regime dynamics related to the control of the potential of this strategic strait are stories of all times. Australia is very interested because all exports go through these two routes [31]. There are four countries as important partners in Southeast Asia; Indonesia, Malaysia, Thailand, and Vietnam from China's perspective. These countries can be categorized as key countries - relations with Beijing. These four countries have been key in expanding the BRI Program across Southeast Asia [32]. Indonesia as a trajectory country, is tested whether it will be able to benefit from this position or only as an observer of the country's trade traffic. President Jokowi's declaration of placing Indonesia as the "World Maritime Axis" is a question mark for Australia, whether the trade route from Papua in the east to Aceh in the west of Indonesia will touch the Indonesian Archipelago Sea Channel (Alur Laut Kepulauan Indoensia=ALKI), which has been a free axis for Australia. During the four years the Sea Highway has been running, it has been seen that the effectiveness and efficiency in the development of Indonesia's maritime and logistical pathways to realize social justice for the Indonesian nation has been seen [33]

About countries, Indonesia is aware of mutual interests. Indonesia has many things in common with Australia despite the inevitable differences. President Jokowi's visit to Australia on February 12, 2020, can be seen to improve relations between the two countries. Even though they each convey their vision, where Indonesia offers cooperation in the maritime sector in the context of "Indonesia as the World Maritime Axis", and Australia presents trilateral cooperation in the Indo-Pacific context, where India, Indonesia, and Australia become anchors in developing partners in the Indo-Pacific region. There are 45 important points in the joint statement, only 10 points outside the Indo-Pacific. They recognize their respective roles in facing the challenging bilateral and regional security environment [34].

Australian Prime Minister Scott Morrison's inaugural visit to Indonesia on August 31, 2018, gave the impression that Australia has a strong interest in Indonesia. This allowance is very strategic in addition to issues of security cooperation and the context of realizing an Indonesia-Australia comprehensive economic partnership agreement (IA-CEPA), which was finally ratified on January 6, 2020, into law. Economically, both parties have a mutual interest. From 2010-2030 Australia is estimated to have earned $\$ 3.2$ billion in profits calculated on the $2008 \mathrm{GNP}$, compared to Indonesia at $\$ 33.1$ billion. The advantage that Indonesia will enjoy 99\% duty-free. Import duty to Australia becomes $100 \%$ free when fully implemented. [35] at the regional level, Australia needs Indonesia no less 
important than the United States. Indonesia's role in ASEAN as an informal leader is necessary for Australia.

\section{Conclusion}

The implication of Free and Open Indo-Pacific (FOIP) strengthens Australia's bargaining position at the international level and in the Pacific region but does not influence Indonesia not to take advantage of China's Belt and Road Initiative (BRI) program. Indonesia focuses on dealing with economic problems and strengthening its position in the ASEAN region. However, Indonesia also has an interest in the Pacific region, especially in resolving the Papua problem. For this reason, Indonesia has a deeper interest in Australia, but not all of Australia's suggestions can be fulfilled because Indonesia still has memories with Australia in the East Timor issue.

If we look more deeply, the FOIP project's essence is not purely an initiative from the United States, but from the big countries in the Asia and Pacific region that are grouped in the quad (India, Japan, Australia, and the United States). The background of quad countries apart from the economic competition also has a strong historical rooted conflict so that the open road to peace with China is in any way closed. Through the Belt and Road Initiative (BRI), China's regional development strategy with infrastructure, investment, and market provision is problematic for developing countries to refuse. The strengthening of ties to economic interests in the region with China does not mean that the country can be dictated by China to make FOIP increase the bargaining of state independence in the region. Even though Indonesia has cooperation in BRI, when dealing with conflicts related to Indonesia's territoriality, it is ready to mobilize military power.

The two countries do not necessarily determine the relationship between Indonesia and Australia in facing global level problems. Australia is committed to being a commonwealth country close to the United States. Meanwhile, the role of the United States in adjudicating the Papua issue has a positive memory. However, because Indonesia has a strategic culture of "free and active", even though it is not compatible, it is not hostile. Indonesia cannot enter into global security forums involving Australia, especially those related to Australia, New Zealand, the United States Security Treaty (ANZUS), and has its history when Soekarno led Indonesia. For this reason, the Australian people still have a memory that Indonesia has the potential as a threat. However, Indonesia's position as a cross-trading area for Australia is forced to maintain mutually beneficial relations.

When the FOIP was strengthened with ASEAN at the regional level, Indonesia would become a quad country like India. This means that a quad is a form of a series of allies in elaborating strength in the region. Indonesia is praised as the ASEAN leader, even though it is an unofficial designation but in the form of unconscious recognition. In the history of ASEA, although many have been ridiculed for not having the ability to make strategic, practical decisions compared to NATO, such a soft regional organization's characteristics are needed in the current democratic era. For this reason, America and China always tease ASEAN members. Indonesia remains in its position as a country that adheres to free and active politics.

\section{References}

[1] C. B. Roberts and A. D. Habir, "Indonesia-Australia Relations: Progress, Challenges and Potential," pp. 195-196, 2015.

[2] A. Gyngell, "Australia-Indonesia," Aust. as an Asia Pacific Reg. Power Friendsh. Flux?, pp. 97-116, 2007.

[3] Y. L. H. Christian Echle, Patrick Rueppel, Megha Sarmah, MultilateralisM in a Changing World order, no. 1. 2018.

[4] C. Six, "Regional Approaches To Security," vol. 18, no. 3, 1994, pp. 50-51.

[5] M. Troitskiy, "The Emerging Great Power Politics and Regionalism: Structuring Effective Regional Conflict Management," Global Policy, vol. 10, no. S2. pp. 14-21, 2019, doi: 10.1111/1758-5899.12677.

[6] M. Beeson, "Australia's Relationship with the United States: The Case for Greater 
Independence," Aust. J. Polit. Sci., vol. 38, no. 3, pp. 387-405, 2003, doi: 10.1080/1036114032000133958.

[7] W. Shicun and J. Colombage, "Indo- Pacific Strategy and China' s Response Indo- Pacific Strategy and China' s Response," Institue China-America Stud., vol. October, no. October, 2019.

[8] R. L. Marsudi, "What future holds for Indonesia-Australia relations.” 2020, [Online]. Available: https://www.thejakartapost.com/academia/2020/02/10/what-future-holds-forindonesia-australia-relations.html.

[9] Kenneth Oye, "Trustees of Princeton University Explaining Cooperation under Anarchy : Hypotheses and Strategies," World Polit., vol. 38, no. 1, pp. 1-24, 2016.

[10] P. M. Morgan, "Book Reviews: INTERNATIONAL RELATIONS December 2001,” Am. Polit. Sci. Rev., vol. 94, no. 4, p. 2001, 2001, doi: 10.2307/2586282.

[11] R. Ayson, "Regional Stability in the Asia-Pacific: Towards a Conceptual Understanding," Asian Secur., vol. 1, no. 2, pp. 190-213, 2005, doi: 10.1080/14799850490961080.

[12] J. M. Montsion, "Ethnography and international relations: situating recent trends, debates and limitations from an interdisciplinary perspective," J. Chinese Sociol., vol. 5, no. 1, 2018, doi: 10.1186/s40711-018-0079-4.

[13] D. R. F. and R. F. L. (Co-chair), GLOBAL SECURITY ENGAGEMENT A New Model for Cooperative Threat Reduction. Washington, DC, 2009.

[14] F. P. Hanggu, L. Hutabarat, S. Harnowo, D. Pertahanan, F. Strategi, and P. Universitas, "INDONESIA'S DEFENCE DIPLOMACY TO THE MEMBER STATES OF THE FIVE POWER DEFENCE ARRANGEMENTS (MALAYSIA, SINGAPORE, AUSTRALIA, NEW ZEALAND, AND UK) YEAR 2000 - 2017," J. Prodi Diplomasi Pertahanan, vol. Vol 4, no. No 1, pp. 39-56, 2018, [Online]. Available: http://jurnalprodi.idu.ac.id/index.php/DP/article/view/201.

[15] J. Gorton, “Australian Defence Statement," Survival (Lond)., vol. 11, no. 4, pp. 116-119, 1969, doi: 10.1080/00396336908440970.

[16] B. Gill, Rising star: China's new security diplomacy, vol. 44, no. 12. 2007.

[17] V. Kaura, "Maritime Affairs : Journal of the National Maritime Foundation of India Incorporating Indo-Pacific and the Quadrilateral into India' s strategic outlook," Marit. Aff. J. Natl. Marit. Found. India, vol. 0, no. 0, pp. 1-25, 2020, doi: 10.1080/09733159.2020.1712012.

[18] J. Mackie and J. Mackie, Australia and Indonesia Australia and Indonesia. 2007.

[19] K. He and M. Li, "Understanding the dynamics of the Indo-Pacific: US-China strategic competition, regional actors, and beyond," Int. Aff., vol. 96, no. 1, pp. 1-7, Jan. 2020, doi: 10.1093/ia/iiz242.

[20] P. Sulistiyanto, "Australian Journal of Political Science Indonesia-Australia Relations in the Era of Democracy: The View from the Indonesian Side Indonesia - Australia Relations in the Era of Democracy: The View from the Indonesian Side," no. June 2014, pp. 37-41, 2010, doi: $10.1080 / 10361140903517742$.

[21] J. M. Hardy, "Peran Australia di Indo-Pasifik - Indo-Pacific Defense Forum.” 2019, [Online]. Available: https://ipdefenseforum.com/id/byline/duta-besar-jane-m-hardy/.

[22] Y. Swastanto, "Indonesia-Australia cooperation: a key to stability in the Indo-Pacific," ASPI The Strategy. 2019, [Online]. Available: https://www.aspistrategist.org.au/indonesia-australiacooperation-a-key-to-stability-in-the-indo-pacific/.

[23] the G. A. Institute, "Regional Outlook," 2012, [Online]. Available: https://www.griffith.edu.au/_data/assets/pdf_file/0037/299818/Regional-Outlook-Paper-42Australia-China-Futures-Dialogue-web.pdf.

[24] A. Gyngell, "Australia - Indonesia," 1986.

[25] Z. Zhexin, "The belt and road initiative: China's new geopolitical strategy?," China Q. Int. Strateg. Stud., vol. 4, no. 3, pp. 327-343, 2018, doi: 10.1142/S2377740018500240.

[26] T. J. Shattuck, "The Race to Zero?: China's Poaching of Taiwan's Diplomatic Allies," Orbis, vol. 64, no. 2, pp. 334-352, 2020, doi: 10.1016/j.orbis.2020.02.003. 
[27] B. Schreer, "Why strategic competition between the US and China is good for Australia The Strategist." 2019.

[28] R. Medcalf, "Australia And China: understanding the reality check *," Aust. J. Int. Aff., vol. 73, no. 2, pp. 109-118, 2019, doi: 10.1080/10357718.2018.1538315.

[29] J. Milia, B. Technologies, Y. Kurniawan, and W. Poespitohadi, "ANALYSIS OF DEFENSE COOPERATION AGREEMENT BETWEEN INDONESIA AND SINGAPORE IN 2007 2017 THROUGH DEFENSE," vol. 2, no. 2, pp. 104-119, 2018.

[30] D. Zandee, Defence cooperation models Lessons learned and usability. 2016.

[31] C. Wirth, "Whose 'Freedom of Navigation'? Australia, China, the United States and the making of order in the 'Indo-Pacific,"” Pacific Rev., vol. 32, no. 4, pp. 475-504, 2019, doi: 10.1080/09512748.2018.1515788.

[32] A. Scobell et al., At the Dawn of Belt and Road: China in the Developing World. 2018.

[33] K. Sa'adah, P. D. Yakti, and S. R. Susanto, "Evaluating 4 years of Jokowi Sea Toll Policy: The concept of Indonesia-Centric connectivity for economic equality," Masyarakat, Kebud. dan Polit., vol. 32, no. 3, p. 290, 2019, doi: 10.20473/mkp.v32i32019.290-302.

[34] P. Parameswaran, "The Growing Indo-Pacific Dimension in Indonesia-Australia Relations The Diplomat," 2020.

[35] Y. A. \& A. Dan, "Key Words: Liberal Economics, IA-CEPA, Trade 139," Andalas J. Int. Stud., vol. 6, no. 1, pp. 79-92, 2017, [Online]. Available:

https://www.researchgate.net/publication/324689523_Implikasi_Perjanjian_Kemitraan_Ekono mi_Komprehensif_Indonesia-Australia_IA-

CEPA_terhadap_Perdagangan_Luar_Negeri_Indonesia/fulltext/5add2c97458515c60f5f2f67/Im plikasi-Perjanjian-Kemitraan-Ekonomi-Komprehe. 